\title{
種々な岩石の $\mathrm{AE}$ による初期応力推定のための
}

基礎的考察

\author{
道廣一利* 畑 浩 二** \\ 藤 原 紀 夫*** 吉 岡 尚 也**
}

\section{Estimation of Initial Stress in Various Rocks by Acoustic Emission}

by

\author{
Kazutoshi Michiniro*, Koji Hata**, Toshio FujiwarA*** \\ and Hisaya YoshioKA**
}

\begin{abstract}
Our previous experimental studies showed that the initial stress in rocks estimated from the Kaiser effect of acoustic emission is not necessarily the maximum stress that the specimen is subjected to, but is correlative to the residual strain in the specimen at the time of testing. The present investigation on the characteristics of the Kaiser effect in various rocks revealed that the initial stress estimated from the Kaiser effect tended to decrease with time after coring. Thus, the experiments to estimate the initial stress existing in a rock mass by means of the Kaiser effect, must be conducted as soon as possible after coring rock samples.
\end{abstract}

Key words : Acoustic emission, Initial stress, Kaiser effect, Rock mass, Non-destructive test

\section{1 緒言}

地山の初期応力（地山から試料を採取した直後の岩 石が有する応力とする）を推定する方法は数多く提案 されているが，現在よく使用される方法の代表的なも のとしては，応力解放法や水圧破砕法などがある。し かしながら, これらの方法には幾つかの問題点がある. 例えば技術的な問題や，計測装置が大がかりになり多 大な費用を要するといった点である.

ところで，材料には，外力によって変形したり破壊 したりする時に微小音を発生する現象がある。この現 象は，変形抢よび破壊に伴って解放されるエネルギー の一部が音響パルスとなって伝播するものであり，ア コースティック・エミッション（以下 $\mathrm{AE}$ と記す） と一般に呼ばれている.この $\mathrm{AE} に は$ 材料によって 差異はあるが，カイザー効果と呼ばれる非可逆的な現 象が確認されている.これは, 過去に荷重が加えられ た材料に再載荷すると, 過去の荷重で生じた最大応力 值までほとんど $\mathrm{AE}$ の発生しない現象である．岩石 でのカイザー効果現象を最初に確認したのは Goodman であり，その後岩石に扔けるカイザー効果につ いて各方面で種々な研究がなれれてきた。 また，カイ ザー効果現象を利用した研究の一つとして，金川ららは， 岩石供試体に一軸単調載荷試験を行い, 供試体から発 生する $\mathrm{AE} レ$ レを計測し, $\mathrm{AE}$ 累積曲線の変曲点を

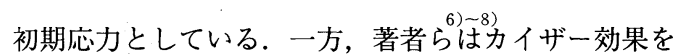
利用して岩盤の初期応力を推定する上での種々な問題 点を提唱し解明してきた。 その結果, カイザー効果か ら推定される応力值は必ずしも岩石供試体が受けた最 大応力值ではなく, 試験時に供試体に残留しているひ ずみ（供試体に応力を加えることによって生じた軸ひ ずみとする）に対応していることを明らかにしだ.7 さ らに, 供試体から応力が解放されると, カイザー効果 より推定される応力值は時間経過に伴って小さくなる ことも明らかにしだ. 本論文では, 残留ひずみと応力 解放後の時間経過の二つに観点をおいて, 種々な岩石 材料におけるカイザー効果特性を解明したものである. $\mathrm{AE}$ のカイザー効果を利用して岩盤の初期応力が推定 できれば，応力解放法や水圧破砕法に比較して装置・ 実験方法とも簡便であり実用的な方法と考えられる.

\section{2 実験装置および使用岩石}

実験に使用した $\mathrm{AE}$ 計測システムの概略を Fig. 1 に 示す。このシステムにより計測される諸量は, 単調載 荷時に扔ける軸応力, 軸ひずみおよび $\mathrm{AE}$ 発生数で ある. 単調載荷にはアムスラー型万能試験機（応力制 御方式）を用いた．載荷速度は $9.8 \mathrm{MPa} / \mathrm{min}$ である. $\mathrm{AE}$ は供試体側面に取り付けた $\mathrm{AE}$ トランスデューサ - (PZT : チタン酸ジルコン酸鉛磁気振動子, 共振周 波数 $140 \mathrm{kHz}, \mathrm{NF}$ 社製 $\mathrm{AE}-901 \mathrm{~S}$ ) で計測した。検

\footnotetext{
$\dagger \quad$ 原稿受理 昭和63年 2 月 16 日 Received Feb. 16, 1988

* 正 会 員 摄南大学工学部 寝屋川市池田中町, Department of Civil Engineering, Setsunan University, Ikeda-nakamachi, Neyagawa

** 正 会 員 (株)大林組技術研究所 清瀬市下清戸, Technical Research Institute, Ohbayashi Corporation, Shimokiyoto, Kiyose

*** (株)大林組技術研究所 清瀬市下清戸, Technical Research Institute, Ohbayashi Corporation, Shimokiyoto, Kiyose
} 


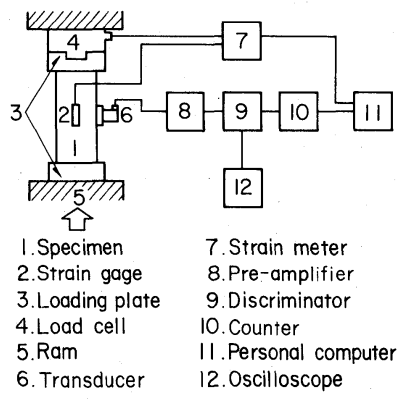

Fig. 1. $\mathrm{AE}$ measuring system.

Table I. Threshold and gain.

\begin{tabular}{l|c|r|c}
\hline \multirow{2}{*}{\multicolumn{1}{c|}{ Identification }} & \multicolumn{2}{|c|}{ Threshold $(\mathrm{mV})$} & \multirow{2}{*}{ Gain (dB) } \\
\cline { 2 - 3 } & $\mathbf{V}_{\mathbf{H}}$ & $\mathbf{V}_{\mathbf{L}}$ & \\
\hline Granite & 400 & 380 & 80 \\
\hline Tuff & 250 & 230 & 90 \\
\hline Mudstone & 100 & 80 & 90 \\
\hline Sandstone & 120 & 100 & 90 \\
\hline Crystalline schist & 200 & 180 & 100 \\
\hline
\end{tabular}

出された $\mathrm{AE}$ は，プリアンプ（ $\mathrm{NF}$ 社製 $\mathrm{AE}-912 ） と$ メインアンプ（ディスクリミネータ， NF 社製 $\mathrm{AE}$ -922 内に装備）により増幅され，あらかじめ設定し たしきい值（Table I 参照）を越え，かつB. P.F (Band Pass Filter, $100 \mathrm{kHz} \sim 200 \mathrm{kHz}$ ) を通過した信 号について包絡線検波法によりカウンタ（NF 社製 AE-932）で計数表示した，一方，軸応力と軸ひずみ は，それぞれロードセル（共和電業社製 LU-5TE） と抵抗線ひずみゲージを用いて計測した。これら計測 された諸量は，パーソナルコンピュータによりリアル タイムで処理・解析した.

実験に使用した岩石試料は, 花崗岩, 凝扊岩, 泥岩, 砂岩および結晶片岩の 5 種類であり, 表面乾燥状態で ある。これら岩石の単位体積重量, 一軸圧縮強度およ び採取場所は Table II に示す通りである. 供試体は, 岩石塊から直径 $30 \mathrm{~mm}$, 高さ $60 \mathrm{~mm}$ および直径 50 $\mathrm{mm}$, 高さ $100 \mathrm{~mm}$ の円柱形に整形した.

Table II. Identification, uniaxial compressive strength $\left(\sigma_{\mathrm{c}}\right)$ and unit weight $(\gamma)$.

\begin{tabular}{l|c|c|l}
\hline \multicolumn{1}{c|}{ Identification } & $\gamma\left(\mathrm{kN} / \mathrm{m}^{3}\right)$ & $\sigma_{\mathrm{c}}(\mathrm{MPa})$ & Location \\
\hline Granite & 25.8 & 131.7 & Inada \\
\hline Tuff & 24.3 & 83.6 & Doujyou \\
\hline Mudstone & 18.3 & 3.4 & Machida \\
\hline Sandstone & 25.9 & 210.3 & Aiki \\
\hline Crystalline schist & 28.9 & 71.2 & Fujioka \\
\hline
\end{tabular}

\section{3 実験結果および考察}

\section{$3 ・ 1$ 繰返し載荷を受けた岩石のカイザー効果 ${ }^{6}, 7$}

著者らは，岩石におけるカイザー効果現象において， 供試体に残留しているひずみの重要性についてすでに 報告している. ここでは，その概略について要約する.

円柱供試体に一軸圧縮応力を繰返し作用させると応 カ〜ひずみ曲線はヒステリシスループを描く これを 繰返し回数と残留ひずみの関係で示せば Fig. 2 となる. 図中破線で示した繰返し 50 回では, 残略ひずみの増 加率は非常に小さく, 一方, 繰返し 10 回程度では残 留ひずみの増加率は繰返し 50 回に比して著しく大き い.ここでは，便宜上繰返し 50 回のものを“ひずみ 飽和状態”, 繰返し 10 回のものを “ひずみ不飽和状 態”の試料とした.

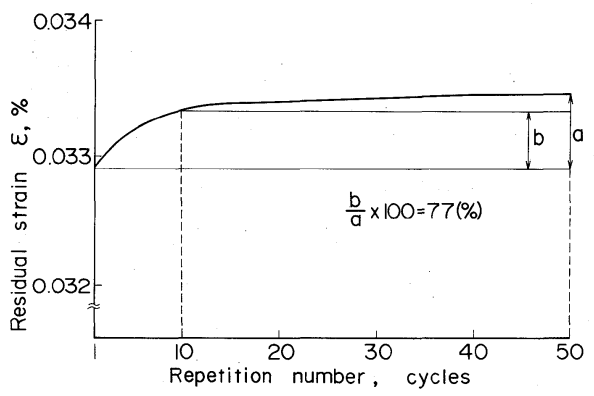

Fig. 2. Relationship between repetition numbers and residual strain.

このような“ひずみ飽和”と“ひずみ不飽和”の 2 種類の状態の供試体を用いて, 一軸試験を行い, $\mathrm{AE}$ を計測した：その結果の一例を軸応力と軸ひずみおよ び AE 累積数関係で示したのが Fig. 3 である. Fig. 3 (a)は“ひずみ飽和状態”の試料で，カイザー効果より $14.8 \mathrm{MPa}$ の見掛けの先行軸応力 (カイザー効果から 推定した軸応力とする）が得られ，これは当初与えた 繰返し軸応力 $14.7 \mathrm{MPa}$ にほぼ等しい. これに対し, “ひずみ不飽和状態”の試料では，カイザー効果から


(Fig. 3(b)).ここに挙げたのは花崗岩の一例にすぎな いが, Table III に示すように凝灰岩，泥岩，砂岩お よび結晶片岩など約 200 体の供試体を用いて行ってお り，一部の供試体（供試体表面にマクロなクラックが 観察されるもの) を除き上記例 (Fig. 3(a)) の結果と 同一となっている.これらの結果より, “ひずみ飽和 状態”の試料では, カイザー効果より推定される先行 軸応力は当初繰返しによって与えた軸応力にほぼ等し いが，“ひずみ不飽和状態”の試料では当初与えた軸 応力よりもかなり低くなっている. いいかえると, カ イザー効果より得られる岩石の先行軸応力は, 当初繰 返しにより受けた最大軸応力に依存するのではなく， 


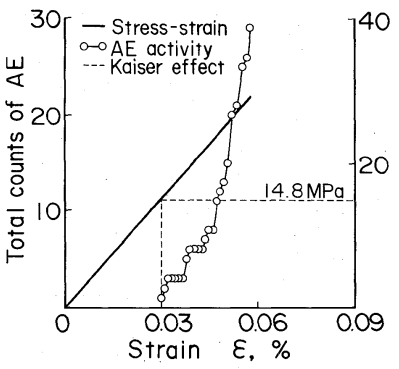

(a) 50 cycles.



(b) 10 cycles.

Fig. 3. Relationships among axial stress, axial strain and $A E$ activity in a granite specimen subjected to cyclic uniaxial compressive stress.

Table III. Relationship between real axial stress applied $\left(\sigma_{\mathrm{A}}\right)$ and axial stress estimated from the Kaiser effect $\left(\sigma_{\mathrm{K}}\right)$.

\begin{tabular}{l|c|c}
\hline \multicolumn{1}{c|}{ Identification } & $\sigma_{\mathrm{A}}(\mathrm{MPa})$ & $\sigma_{\mathrm{K}}(\mathrm{MPa})$ \\
\hline Granite & 14.7 & 14.2 \\
\hline Tuff & 14.7 & 14.9 \\
\hline Mudstone & 0.9 & 1.02 \\
\hline Sandstone & 14.7 & 14.8 \\
\hline Crystalline schist & 14.7 & 15.0 \\
\hline
\end{tabular}

供試体に残留している軸ひずみに大きく依存している といえる.

地山に抢ける岩盤の応力の分布は極めて複雑で，一 般には三次元応力状態にあると考えられる。したがっ て，上述したような一次元的な応力によるカイザー効 果の考察も当然必要であるが，地山の応力状態に近い 状態でのカイザー効果特性を明らかにしなければなら ない，そこで，高圧三軸圧縮試験機を用い種々な軸圧 $\left(\sigma_{1}\right)$ と側圧 $\left(\sigma_{3}\right)$ のもとで主応力比 $\left(\sigma_{3} / \sigma_{1}\right)$ を一定 に保ちながら繰返し載荷を行い，供試体に三次元的な 先行応力を与えた。繰返し回数と軸方向の残留ひずみ の関係は Fig. 2 と同様な傾向であった．残留ひずみに 着目すれば，繰返し回数が 50 回程度になればひずみ の増加がほほ停止している。この状態を三軸応力状態 における “ひずみ飽和状態”の試料とする，なお，供 試体に作用させた軸圧 $\left(\sigma_{1}\right)$ と側圧 $\left(\sigma_{3}\right)$ の組み合わ せを Table IV に示す.このような種々の主応力比
Table IV. Axial compressive stress $\left(\sigma_{1}\right)$ and confining stress $\left(\sigma_{3}\right)$

\begin{tabular}{c|c}
\hline$\sigma_{1}(\mathrm{MPa})$ & $\sigma_{3}(\mathrm{MPa})$ \\
\hline 4.9 & 4.9 \\
\hline 6.9 & 4.9 \\
\hline 7.8 & 4.9 \\
\hline 9.8 & 4.9 \\
\hline 11.8 & 4.9 \\
\hline 14.7 & 4.9 \\
\hline 19.6 & 4.9 \\
\hline
\end{tabular}

$\left(\sigma_{3} / \sigma_{1}\right)$ のもとでの繰返し 50 回終了後，三軸セルよ り供試体を取り出し, 供試体表面に抵抗線ひずみゲー ジを貼付した後，直ちに一軸単調載荷を行い，AEを 計測した。

実駼結果の一例を Fig. 4 に示す. 図は, 主応力比 $\left(\sigma_{3} / \sigma_{1}\right)$ がそれぞれ 1.0 と 0.25 のもとで繰返し載荷を 行った後，一軸試験における軸応力と軸ひずみおよび $\mathrm{AE}$ 累積数の関係を示したものである. 図より推定さ れる見掛けの軸応力は Fig. 4 (a)では $4.7 \mathrm{MPa} て ゙ ，(b)$

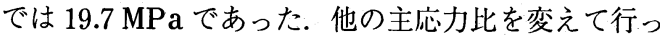
た結果を Table V に示す。このように，実験は種々 の主応力下で行ったにもかかわらず，カイザー効果よ り推定される見掛けの先行軸応力は側圧 $\left(\sigma_{3}\right)$ の影響 をまったく受けておらず，繰返し載荷により作用させ

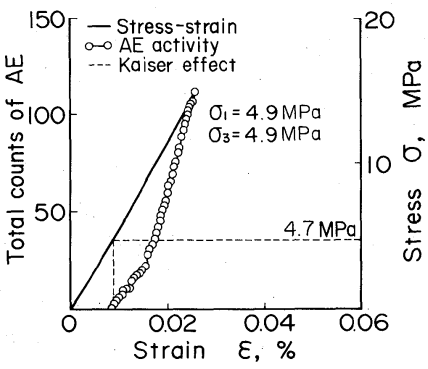

(a) 50 cycles.



(b) 10 cycles

Fig. 4. Relationships among axial stress, axial strain and $\mathrm{AE}$ activity in a granite specimen subjected to cyclic triaxial compressive stress. 
Table V. Relationship between principal stress ratio $\left(\sigma_{3} / \sigma_{1}\right)$ and axial stress estimated from the Kaiser effect $\left(\sigma_{\mathrm{k}}\right)$.

\begin{tabular}{c|c|c|c}
\hline $\begin{array}{c}\sigma_{1} \\
(\mathrm{MPa})\end{array}$ & $\begin{array}{c}\sigma_{3} \\
(\mathrm{MPa})\end{array}$ & $\begin{array}{c}\sigma_{3} / \sigma_{1} \\
(\mathrm{MPa})\end{array}$ & $\begin{array}{c}\sigma_{\mathrm{K}} \\
(\%)\end{array}$ \\
\hline 4.9 & 4.9 & 1.00 & 4.7 \\
\hline 6.9 & 4.9 & 0.71 & 7.0 \\
\hline 7.8 & 4.9 & 0.63 & 8.1 \\
\hline 9.8 & 4.9 & 0.50 & 9.7 \\
\hline 11.8 & 4.9 & 0.42 & 11.4 \\
\hline 14.7 & 4.9 & 0.33 & 14.8 \\
\hline 19.6 & 4.9 & 0.25 & 19.7 \\
\hline
\end{tabular}

た軸圧（ $\left.\sigma_{1}\right)$ のみの值を示している，厳密にいえば， 主応力比の変化とともに $\mathrm{AE}$ 発生数には若干の変化 がみられるが，カイザー効果より得られる値に関して は，側圧の大小を考慮しなくてもよいと考えられる.

\section{$3 \cdot 2$ 一定軸応力を受けた岩石のカイザー効果}

3 ・1では, 一軸および三軸圧縮による繰返し載荷を 行い, “ひずみ飽和状態”と “ひずみ不飽和状態”で のカイザー効果特性について要約を記した，その結果， “ひずみ飽和状態”の供試体を用いた場合のみ，カイ ザー効果より推定される応力は, 当初繰返し載荷によ り作用させた応力値とほぼ等しい值となった。

ところで，岩盤は長期間にわたり荷重を受けクリー プは完了していると考えられる，そのためここでば, $3 \cdot 1$ の繰返し荷重を受けた場合と異なり, 一定軸応力 を受けた供試体のカイザー効果特性について考察する. 一定軸応力 $14.7 \mathrm{MPa}$ のもとで軸ひずみの増加がほぼ 停止した. いわゆる “ひずみ飽和状態”と軸ひずみの 増加が顕著に認められる “ひずみ不飽和状態” との二 種類の供試体を作成した。一定軸応力を除荷したのち ただちに一軸試験を行い AE を計測した．Fig. 5 に実 験結果の一例を軸応力と軸ひずみおよび $\mathrm{AE}$ 累積数 の関係で示す．Fig. 5 (a)では，カイザー効果より推定 される見掛けの先行軸応力は $14.7 \mathrm{MPa}$ となっており， 当初与えた一定軸応力 $14.7 \mathrm{MPa}$ にほぼ等しい. 一方, クリープひずみの増加が顕著に見受けられる状態，い わゆる “ひずみ不飽和状態”では, 当初与えた一定軸 応力よりもかなり低い值を示した (Fig. 5(b)).

ここに挙げたのは一例にすぎないが, 全ての結果に ついて，“ひずみ飽和状態”の試料では，カイザー効 果より当初与えた一定軸応力を数パーセントの誤差内 で推定できるが, “ひずみ不飽和状態”ではかなり低 い值となった。したがって，クリープ載荷の場合も繰 返し載荷の場合と同様に“ひずみ飽和状態” の供試体 を用いれば，当初与えた一定軸応力をカイザー効果よ り正確に推定できることが明らかとなった。

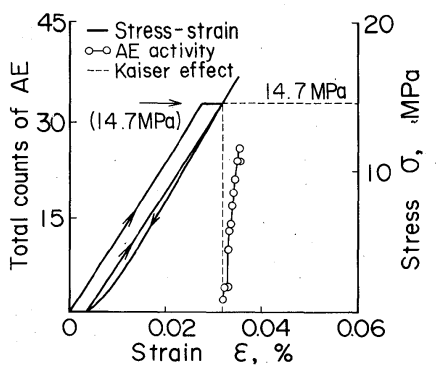

(a) State of strain increment equal to zero.

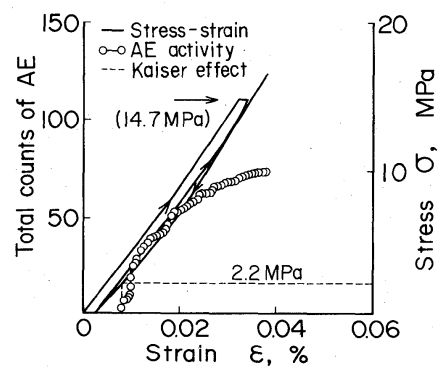

(b) State of strain increment not equal to zero.

Fig. 5. Relationships among axial stress, axial strain and $\mathrm{AE}$ activity in a granite specimen subjected to constant uniaxial compressive stress.

\section{$3 \cdot 3$ 応力解放後の時間経過とカイザー効果の関係}

地山から岩石試料を採取し試験を行うまでには, 試 料の輸送や整形などのためにタイムラグが生ずる。こ のため岩石試料は応力解放後の時間経過に伴って一般 にひずみ回復（膨張）を生ずる. したがって，地山か ら岩石試料を採取した後 (応力解放後) の時間経過が カイザー効果にいかに影響を及ぼすかを調べる必要性 がある．その照査のための試験として, $14.7 \mathrm{MPa} の$ 一定軸応力の下で “ひずみ飽和状態”とし，一定軸応 力除荷後, 恒温 - 恒湿な場所で種々な長さの期間放置 した供試体に一軸単調載荷試験を行い $\mathrm{AE}$ を計測し た。なお，今回の試験での試料放置期間は，1.5，3， $4 ， 5 ， 6 ， 7.5 ， 9 ， 11.5 ， 14$ および 20 日であっ た. 縦軸にカイザー効果より求めた見掛けの先行軸応 力を，横軸に放置期間をとり結果を整理すると Fig. 6 のようになる。 その結果，放置期間が 4 日目位までは， カイザー効果より推定される見掛けの先行軸応力は予 め与えた一定軸応力にほぼ等しくなっているが，4 日 を越えると放置期間が増すにつれて小さな值となって いる.このことは，用いた試料が一時的にある一定荷 重下で “ひずみ飽和状態” であっても，それを長期間 放置することにより残留ひずみが回復し，ある一定荷 重下に扔ける“ひずみ不飽和状態”の試料と同等にな り，予め与えた応力よりも推定軸応力が低くなるもの と考えられる. 


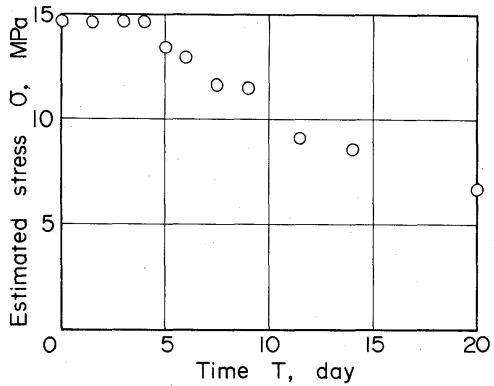

Fig. 6. Relationship between axial stress estimated from the Kaiser effect and number of elapsed days.

ただしここに述べた “ひずみ飽和状態”および “ひずみ不飽和状態”は実験室レベルのものである. 一方, 地山の岩石は一般に極めて長期間載荷状態にあ ク，“ひずみ飽和状態”であると考えられる。した がって地山より採取した岩石と試験室内で短期の載荷 をした岩石とでは，残留ひずみの回復の様相が異なる かもわからない. また, 地山に扔ける岩石は三次元応 力状態下でのクリープであり, 今回の実験は一軸圧縮 応力下に扔けるクリープ試験の結果である.

以上より，一定軸応力下にある供試体から軸応力を 解放させ，ある時間以上経過すると，カイザー効果よ り推定される載荷軸方向の応力はあらかじめ作用させ た一定軸応力よりも小さくなることが明らかとなった. しかし，これはあくまでも一定軸応力の載荷期間が 7 〜10 日間という実験室内のレベルであり，原位置岩 盤のように非常に長期にわたって種々な応力を受けた 状態の結果ではない.

\section{$3 \cdot 4$ 原位置から採取した岩石のカイザー効果}

室内に招ける実験結果が，そのまま原位置における 岩石に適用できるか否かを検討した。ここでは，原位 置から採取した岩石試料を用い, 試料採取後 (応力解 放後）の時間経過がカイザー効果より推定される応力 にどのような影響を及ぼすかを調べた.

使用した岩石試料は，適切に選んだダムにおける土 被り約 $80 \mathrm{~m}$ のバルブ室建設現場の側壁から掘削長さ $11 \mathrm{~m}$ の水平ボーリングを行い, 直径 $75 \mathrm{~mm}$ の岩石コ アを採取した。採取地点は Fig. 7 の概略図に示すよう に急傾斜をなす斜面の下にあたる，付近の岩種は主に 花崗岩で, その一軸圧縮強度は約 $240 \mathrm{MPa}$, 単位体 積重量は $26.3 \mathrm{kN} / \mathrm{m}^{3}$ の良質なものであった．掘削長 さ $11 \mathrm{~m}$ の水平ボーリングの内, 側壁から約 $4 \mathrm{~m}$ 位ま での部分で採取した岩石コアには, 節理の発達が見ら れると共に，青灰色や緑灰色の薄いシーム層が介在し ていたここの部分は，空洞を掘削したことによる影響 （応力集中）を受けていると考えられるので，実験対



Fig. 7. Location of rock sample coring.

\section{象外の試料とした.}

Fig. 8 に示したようにI，II，III方向を軸とする直 径 $30 \mathrm{~mm}$, 高さ $60 \mathrm{~mm}$ の円柱供試体を整形し, 供試 体表面に低抵抗線ひずみゲージを貼付した後，直ちに 一軸単調載荷を行い, AE を計測した. Fig. 9 に結果 の一例を示す。この図に示した試料は Fig. 8 における I 方向のものであり，それぞれ岩石コア採取後 1 日お よび 10 日間放置した後，一軸試験を行った結果であ る. Fig. 9(a)は試料採取後の放置期間が 1 日のもので あり，カイザー効果より推定される軸応力は 1.0 MPaである. 一方, Fig. 9(b)は 10 日間放置したもの で, 推定応力は $0.6 \mathrm{MPa}$ となっており, 同一場所, 方向の試料にもかかわらずカイザー効果より推定され る軸応力は約半分の值となっている。これらのデー夕 をFig. 8 に示した各方向（I， II， III）ごとに，横軸 を試料放置経過日数, 縦軸をカイザー効果より推定さ れる応力として示せば Fig. 10 となる。 これらの図よ り，いずれの方向においても岩石コア採取後 5 日目位 までは，カイザー効果より推定される軸応力はほぼ一 定值を呈しているが， 5 日目以降では経過日数に伴っ て推定軸応力は小さくなっている.ここで, 前節で示 した室内での結果と Fig. 10 を併せて描くと Fig. 11 と なる. 図中の印は， $7 \sim 10$ 日間 $14.7 \mathrm{MPa}$ の一定軸

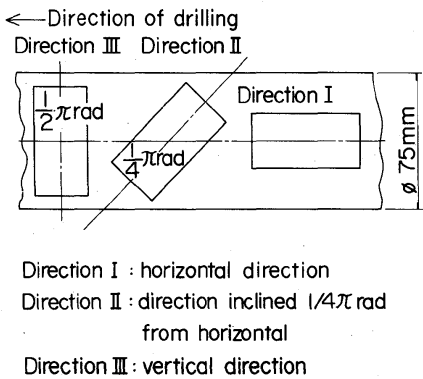

Fig. 8. Cylindrical specimens (diameter : $30 \mathrm{~mm}$, length : $60 \mathrm{~mm}$ ). 


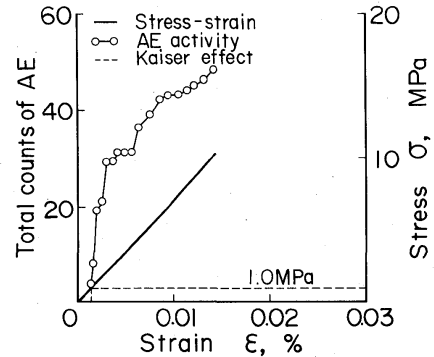

(a) 1 day after rock sample coring.

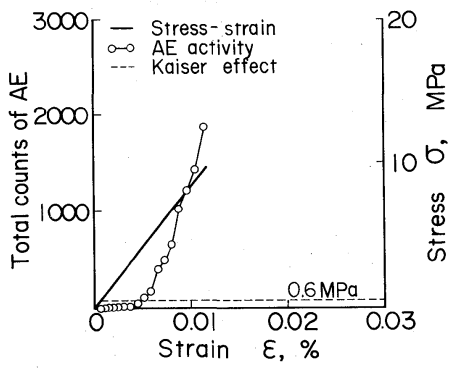

(b) 10 days after rock sample coring.

Fig. 9. Relationships among axial stress, axial strain and $\mathrm{AE}$ activity in a granite specimen shaped in the horizontal direction (direction I).

応力下でクリープさせ，その後除荷し，種々の期間放 置した後, 一軸単調載荷を行いカイザー効果より得ら れた見掛けの先行軸応力を示したものであり， $\triangle$, および○印はそれぞれ前述した Fig. 10 (a)，(b)および (c)である. ○印ではあらかじめ与えた軸応力とカイザ 一効果より推定される応力とがほぼ同じである期間は

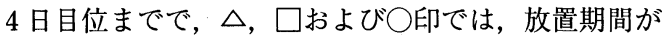
5 日目位までであれば，ほぼ同じ值を示しており，室 内で強制的に先行軸応力を与えた場合と傾向を同じく している.このことは，試料採取時の乱れとか，応力 解放に伴ってひずみの回復が生ずるが，もし地山内に おける応力と試料採取直後における応力との間にあま り差がないとすれば（正確に言えば地山から岩石を採 取した後応力分布の状態はかわっている)，これらの 結果より試料採取後数日間以内に $\mathrm{AE}$ 試験を行えば, かなり正確に岩盤の初期応力を測定できるのではない かと考えられる.

いずれにしても，カイザー効果から推定される応力 は, 応力解放後の時間経過に伴って小さく推定される ことが認められる (Fig. 11 参照)。そのため，地山か ら岩石試料を採取した後は，ひずみがあまり回復しな いうちに $\mathrm{AE}$ 試験を行わなければ，初期応力を正確 に求めることができないことが十分に推測される.

$3 \cdot 5$ AE 法により推定した主応力およびその方向

限られた室内実験結果であるが，三軸試験を行った 結果から，推定される見掛けの先行軸応力は側圧

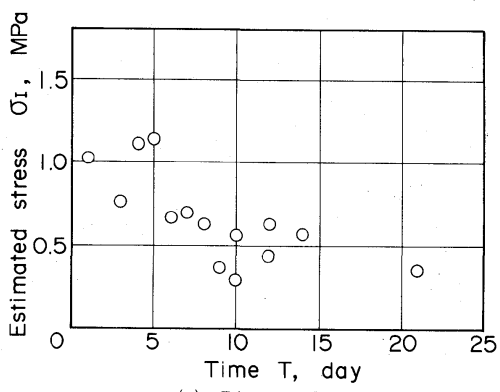

(a) Direction I.

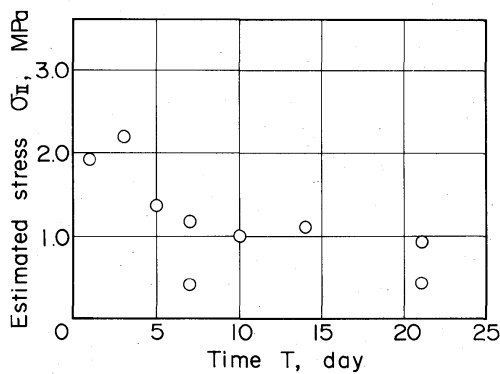

(b) Direction II.

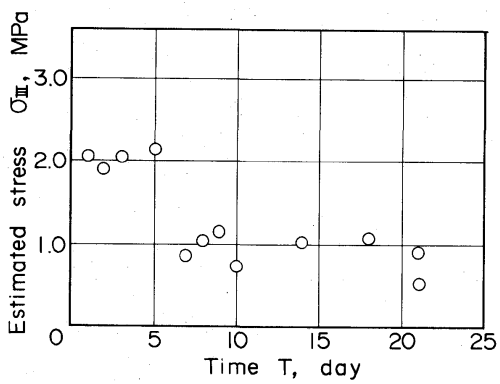

(c) Direction III

Fig. 10. Relationship between initial stress estimated from Kaiser effect and number of elapsed days in specimens shaped.

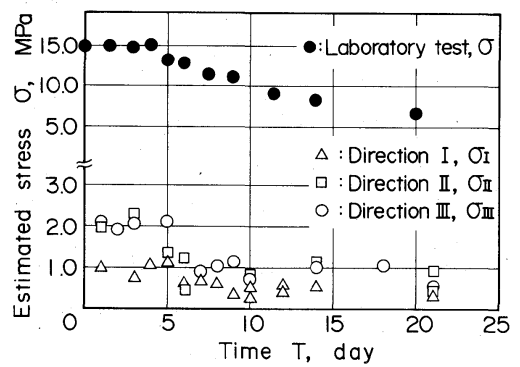

Fig. 11. Comparison of results in Fig. 6 and 10.

$\left(\sigma_{3}\right)$ の影響をまったく受けておらず，軸圧（ $\left.\sigma_{1}\right)$ の 值を示していることがわかった，そのため，カイザー 効果から求められる值は載荷軸方向の応力成分である ことが明らかとなった。このことをべースにし，地山 における岩盤の最大主応力 $\sigma_{1}$, 最小主応力 $\sigma_{3}$ および 主応力の傾斜角 $\theta$ を Fig. 12 より求めることができる. 
$\sigma_{1}$
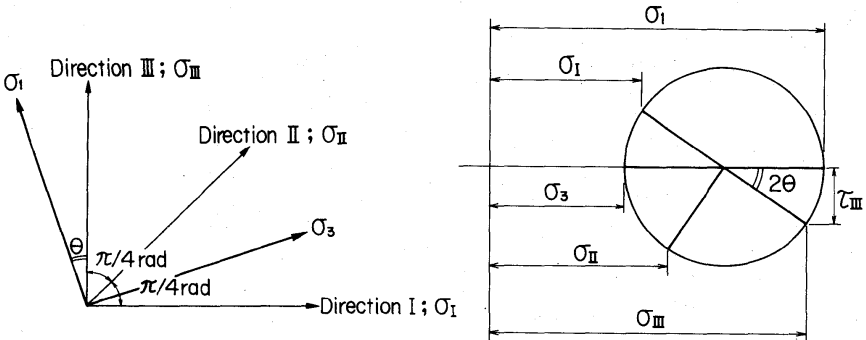

Fig. 12. Mohr's circle of three stress $\left(\sigma_{\mathrm{I}}, \sigma_{\mathrm{II}}, \sigma_{\mathrm{III}}\right)$ components and principal stress $\left(\sigma_{1}, \sigma_{3}\right)$

すなわち，ある平面内において水平軸方向を基準にと り鉛直方向へ $0 \mathrm{rad}, \pi / 4 \mathrm{rad}, \pi / 2 \mathrm{rad}$ 傾いた三方 向の試料を用い, カイザー効果より得られる応力成分 をそれぞれ $\sigma_{\mathrm{I}}, \sigma_{\mathrm{II}}, \sigma_{\mathrm{III}}$ とする．また，この平面内に おける最大主応力と最小主応力をそれぞれ $\sigma_{1}, \sigma_{3}$ と し, 鉛直軸方向の応力成分 $\sigma_{\text {III }}$ と最大主応力 $\sigma_{1}$ とのな す角を $\theta$ とする. ただし，ここでは圧縮応力を正， 最大主応力の傾き $\theta$ は鉛直軸方向の応力成分 $\sigma_{\text {III }}$ から 反時計まわりを正とする．Fig. 12 ょり，三応力成分 $\sigma_{\mathrm{I}}, \sigma_{\text {II }}, \sigma_{\text {III }}$ は最大主応力 $\sigma_{1}$, 最小主応力 $\sigma_{3}$ および主 応力の傾斜角 $\theta$ を用いると以下のようになる.

$$
\begin{aligned}
& \sigma_{\mathrm{I}}=\frac{\sigma_{1}+\sigma_{3}}{2}-\frac{\sigma_{1}-\sigma_{3}}{2} \cos 2 \theta \\
& \sigma_{\text {II }}=\frac{\sigma_{1}+\sigma_{3}}{2}-\frac{\sigma_{1}-\sigma_{3}}{2} \sin 2 \theta \\
& \sigma_{\text {III }}=\frac{\sigma_{1}+\sigma_{3}}{2}+\frac{\sigma_{1}-\sigma_{3}}{2} \cos 2 \theta
\end{aligned}
$$

また，鉛直軸方向の応力成分 $\sigma_{\text {III }}$ に対するせん断応力 を $\tau_{\text {III }}$ をすれば次のようになる.

$$
\tau_{\text {III }}=-\frac{\sigma_{1}-\sigma_{3}}{2} \sin 2 \theta
$$

これらを変形すれば, 最大主応力 $\sigma_{1}$ と最小主応力 $\sigma_{3}$ は以下のようになる。

$$
\left.\begin{array}{c}
\sigma_{1} \\
\sigma_{3}
\end{array}\right\}=\frac{\sigma_{\mathrm{I}}+\sigma_{\mathrm{II}}}{2} \pm \frac{\sqrt{2}}{2} \sqrt{\left(\sigma_{\mathrm{I}}-\sigma_{\mathrm{II}}\right)^{2}+\left(\sigma_{\mathrm{II}}-\sigma_{\mathrm{II}}\right)^{2}}
$$

さらに，最大主応力 $\sigma_{1}$ の傾き $\theta$ は式(1)より

$$
\tan 2 \theta=\frac{2 \sigma_{\text {II }}-\left(\sigma_{\mathrm{I}}+\sigma_{\text {III }}\right)}{\sigma_{\mathrm{I}}-\sigma_{\text {III }}}
$$

となる.

上式を用い，Fig. 10 における試料採取後 5 日以内 の $\sigma_{\text {I }}, \sigma_{\text {II }}, \sigma_{\text {III }}$ より, 最大主応力 $\sigma_{1}$, 最小主応力 $\sigma_{3}$ 打 よび傾き $\theta$ を計算すると $\sigma_{1}=2.1 \mathrm{MPa}, \quad \sigma_{3}=0.9 \mathrm{MPa}$ および $\theta=-0.3 \mathrm{rad}$ となる. 一方, 近接地点におい て応力解放法で初期応力を推定している. その結果は, $\sigma_{1}=4.6 \mathrm{MPa}, \sigma_{2}=2.1 \mathrm{MPa}, \sigma_{3}=0.3 \mathrm{MPa}$ であった. $\mathrm{AE}$ 法による計測が 2 次元を対象にしているのに対し, 応力解放法では 3 次元を対象としている，さらに，応 力解放法によるデー夕が一計測しかないため詳しい議
論はできないが，今後多くのデー夕を 集めることにより $\mathrm{AE}$ 法の有効性を さらに検証する必要がある.

\section{4 結論}

$\mathrm{AE}$ のカイザー効果を利用し，岩盤 の初期応力を推定する上での問題点の 一つである応力解放後の時間経過に着 目して，種々な岩石のカイザー効果特 性を実験的に検討した．得られた結果 をまとめると以下のようになる.

(1)種々な岩石（5種類）においても， $\mathrm{AE}$ のカイザー効果は先行応力に依存するのではなく, 供試体のひずみ飽和の程度に影響される。

(2)地山から採取した岩石試料を恒温・恒湿な場所で 種々の期間放置した後，一軸単調載荷を行い $\mathrm{AE}$ 計測し，カイザー効果より見掛けの先行軸応力を求め た結果，採取後 5 日目位を境にして見掛けの先行軸応 力は急激に小さくなった. この傾向は，室内で一定軸 応力を与えた後, 一軸単調載荷により求めた場合と同 一傾向であった.

以上のようなことをふまえ，今後種々な問題を解決 することにより， $\mathrm{AE}$ 法による初期応力の推定が有効 な手段になりうると考えられる.

最後に, 本研究を遂行するにあたり終始一貫して適 切なご指導をいただいた京都大学名誉教授, 村山朔郎 博士に深く感謝の意を表します.

（昭和59年10月 23 日 第 7 回国際 AE シンポジウムにて講演）

\section{参考文 献}

1) J. Kaiser, Archiv für des Eisenhüttenwesen, 24, 43 (1953).

2 ) R. E. Goodman, Geo. Soc. of Am., 74, 487 (1963).

3) K. Mogi, Bell. of the Earthquake Res. Inst., 40, 125 (1962).

4 ) S. Yoshikawa and K. Mogi, Tectonophysics, pp. 323 (1981).

5 ）金川 忠, 林 正夫, 仲佐博裕, 土木学会論文報告集, 258号, pp. 63 (1977).

6 ) K. Michihiro, T. Fujiwara and H. Yoshioka, the 26th U. S. Sympo. on Rock Mech., pp. 557 (1985).

7) K. Michihiro, H. Yoshioka, K. Hata and T. Fujiwara, 4th Conf. AE/MA in Geo. Structure and Materials, (1985) in print.

8 ) S. Murayama, K. Michihiro, J. Saito, T. Fujiwara, H. Yoshioka and K. Hata, Proc. of the 7th Int. AE Sympo., pp. 586 (1984). 